\title{
Plant available silicon in sugarcane soils and its relationship with soil properties, leaf silicon and cane yield
}

D.B. PHONDE, P.S. DESHMUKH, K. BANERJEE AND P.G. ADSULE

\author{
MEMBERS OF RESEARCH FORUM: \\ Corresponding author : \\ D.B. PHONDE, Vasantdada Sugar \\ Institute, Majari (Bk), PUNE (M.S.) \\ INDIA \\ Email: Db.phonde@ vsisugar.org.in
}

Co-authors :

P.S. DESHMUKH, Department of Agro-

Chemicals and Pest Management,

Shivaji University, KOLHAPUR (M.S.)

INDIA

K. BANERJEE AND P.G. ADSULE,

National Research Centre for Grapes,

Manjri Farm, PUNE (M.S.) INDIA
Received : 05.06.2014; Revised : 22.09.2014; Accepted : 08.10.2014

\section{Summary}

A survey of 74 sugarcane growing fields from South, Central, Marathwada and Vidharbha regions of Maharashtra state (India) was undertaken for plant available silicon (PA-Si) status in soil extracted with $0.5 \mathrm{M}$ ammonium acetate $(\mathrm{pH} 4.8), 0.5 \mathrm{M}$ acetic acid and $0.01 \mathrm{M}$ calcium chloride and physico-chemical properties. The plant available silicon extracted by $0.5 \mathrm{M}$ ammonium acetate, $0.5 \mathrm{M}$ acetic acid and $0.1 \mathrm{M}$ calcium chloride from soils ranged from 31.42 to 465.76 , 66.76 to 590.19 and 12.65 to $134.40 \mathrm{mg} \mathrm{kg}^{-1}$ with the mean content of 194.19 , 359.71 and $63.63 \mathrm{mg} \mathrm{kg}^{-1}$, respectively. Extraction pool of PA-Si was found maximum by $0.5 \mathrm{M}$ acetic acid followed by $0.5 \mathrm{M}$ ammonium acetate and least by $0.01 \mathrm{M}$ calcium chloride which were positively correlated to each other. The relationship between PA-Si extracted by different extractants with soil properties revealed that plant available Si content in soil increased with $\mathrm{pH}$, clay content, exchangeable cations and cation exchange capacity of the soil. Phosphate availability was increased in higher PA-Si containing soils. Of the surveyed plots 33 fields monitored for leaf $\mathrm{Si}$ concentration at 120 days after sugarcane plantation, cane and sugar yield showed positive strong correlation with $0.5 \mathrm{M}$ acetic acid extractable PA-Si compared to $0.5 \mathrm{M}$ ammonium acetate. It revealed that the $0.5 \mathrm{M}$ acetic acid was suitable extractant to measure plant available silicon from the soil.

Key words : Sugarcane, Plant available silicon, Physico-chemical properties, Cane and sugar yield

How to cite this article : Phonde, D.B., Deshmukh, P.S., Banerjee, K. and Adsule, P.G. (2014). Plant available silicon in sugarcane soils and its relationship with soil properties, leaf silicon and cane yield. Asian J. Soil Sci., 9(2): 176-180. 